\title{
Grammar aspect of English and German acquisition in Russian medium
}

\author{
Natalia Bhatti $^{1, *}$, Ekaterina Kovsh $^{1}$, Elena Kharitonova ${ }^{1}$ and Irina Sapranova ${ }^{1}$ \\ ${ }^{1}$ Moscow Region State University, 10A, Radio Str., 105005, Moscow, Russia
}

\begin{abstract}
Bilingualism and multilingualism in education has become a reality in the modern multi-cultural world. In recent years, there have been numerous studies proving benefits from bilingual and multilingual approaches in education. Proficiency in second or third languages has many benefits starting from excellence in academic studies and easier access to global information resources and ending with personal awareness of cultural diversity of the world and global mobility. There is overwhelming evidence that English and German are the most popular languages chosen for the Unified State Exam in a foreign language in Russia. The study shows that a worthwhile investment of time and effort into grammatical aspect of language acquisition is of great value. The research is based on the data collected in an experiment involving 38 senior students of gymnasium 6 in Ivanteevka (Moscow Region, Russia).The result of the experiment proves the efficiency of the translanguaging approach to teaching English or German grammar. The successful formation of grammar skills in oral and written speech is based on the comparative analysis of the languages (L1, L2, L3). The mistakes which were predetermined by the differences in grammatical features of the target languages were eliminated by laying emphasis on developing mostly productive rather than reproductive skills. The cognitive exercises used the experiment enlarged the students' meta-disciplinary knowledge and helped them to master analytical skills. By comparing cultural, linguistic and social phenomena existing in L1, L2 and L3 the experimentees came to realize their belonging to the global community and the necessity of application of their language skills to successfully function as an equal member of this community. This approach could be widely used in comprehensive schools in the Russian Federation, adding to the positive effects on intellectual growth and enhancing students` linguistic, emotional and personal development.
\end{abstract}

\section{Introduction}

The problem of a second and third language acquisition by learners whose native language is Russian remains urgent and demands great attention. Due to the recent changes

*Coresponding author: taniasemina@gmail.com 
in the educational process and in the educational system of the country in general the approach to teaching languages in modern comprehensive schools should be reconsidered and modified. Despite the new methods introduced lately into the process of teaching, Russian learners do not only make grammar mistakes both in oral and written speech but avoid using certain grammar constructions determined by the given context.

The principle of teaching a second or third language basing on the native language and the native linguaculture is increasing in importance in the modern polycultural and multilingual society. Bilingual development and equal acquisition of two cultures become a priority in teaching languages since native linguacultural identity can only manifest itself through the contact with other cultures $[1,2]$.

These facts predetermine the necessity of the study undertaken by the authors of the current work. The target languages the study focuses on are English and German. The students whose abilities to acquire grammar aspects of the above mentioned languages we examined were Russian native speakers. It has been hypothesized that application of a translanguaging approach in a classroom might bring an overall positive effect on learners. Teaching a second language as a separate language system posited before as a necessary means for language learning does not seem to be effective. It is the language experience gained through L1 acquisition which an individual has to rely on when acquiring L2. It leads to adaptability and cooperation of language systems [3].

The assumption of the necessity of using a studied language as a tool of cognition may be another cornerstone in the selection of teaching and learning materials techniques. Serving communicative purpose language shares knowledge as well as develops it. It organizes and constructs an individual's thinking process. The participants of communication co-construct the linguistic reality through sharing meanings and expressing their ideas, thus building knowledge together using language as a tool. When teaching a second language is based on such valuable experience the language acquisition becomes purposeful and conscious $[4,5]$.

\section{Materials and Methods}

The current research analyses the grammatical aspect of language acquisition. While reflecting upon the problems in mastering grammar categories of second and third language we studied and summarized the work of expert examiners in the Unified State Exam in a foreign language in Russia. The students who choose to sit for an examination in English or German on leaving school are generally fluent enough in the respective languages which enabled us to assess adequately the problems existing in the field of grammar acquisition and put forward a conjecture that the root of the problems might lie in the wrong understanding of the role of the first language in the teaching process and, consequently, in the wrong prioritizing of goals and tasks [6].

The present study is based on the data collected in an experiment which involved 38 (24 English and 14 German) senior students of gymnasium 6 - a comprehensive school in the town of Ivanteevka in Moscow Region. All the experiment participants were divided into a control group which included 12 English students and 7 German students and a group which followed the regular studying routine. In order to get an insight into the kind of mistakes made by the Russian native learners of English and German we conducted diagnostic tests - a range of tests aimed at detecting typical grammar errors made by learners on the level of morphology and syntax - which included written and oral practices. The tests corresponded to B1 and B 2 levels of Common European Framework of Reference. For assessing the students' language proficiency in L2, in English or German respectively, the participants of both groups were asked to do multiple choice tasks, offering to select the right grammatical form / preposition / collocation item etc. The 
learners were also invited for an interview in which they had to speak on different topics which made it possible to assess their oral grammar skills.

After the level assessment we applied the translanguaging approach to teaching English or German grammar to the control group which included 12 English students and 7 German students selected randomly out of total 38 students participating in the experiment. Meanwhile, a regular school program teaching activities were used for English or German grammar acquisition while working with the remaining 19 students. The experiment continued for 3 years from September 2016 to June 2019, involving the students of the $9^{\text {th }}$ $11^{\text {th }}$ forms. The progress of the control group learners was measured regularly at the end of each school year during the testing period and the results were thoroughly analyzed and compared. The collected statistical data enabled the authors to assess the effectiveness of the selected teaching methods. On completion of the period diagnostic tests were conducted again to measure the progress of the learners.

The sum total of oral and written mistakes in different grammar domains in the operating languages made by the students at the beginning and at the end of the experiment is presented in the table below.

Table 1. Typical grammar mistakes in English and German at the beginning and at the end of the experiment.

\begin{tabular}{|c|c|c|c|c|c|c|c|}
\hline \multirow{2}{*}{ 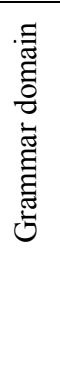 } & \multirow{2}{*}{ 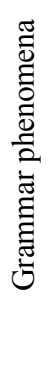 } & \multirow[t]{2}{*}{$\begin{array}{l}\text { Common mistakes in } \\
\text { English }\end{array}$} & \multicolumn{2}{|c|}{$\begin{array}{l}\text { Percentage of } \\
\text { mistakes }\end{array}$} & \multirow{2}{*}{$\begin{array}{l}\text { Common } \\
\text { mistakes in } \\
\text { German }\end{array}$} & \multicolumn{2}{|c|}{$\begin{array}{l}\text { Percentage of } \\
\text { mistakes }\end{array}$} \\
\hline & & & $\begin{array}{l}\text { Regular } \\
\text { group } \\
12 \quad \text { st } \\
\text { (initial } \\
\text { results / } \\
\text { final } \\
\text { results) }\end{array}$ & $\begin{array}{l}\text { Contol } \\
\text { group } \\
12 \mathrm{st} \\
\text { (initial } \\
\text { results / } \\
\text { final } \\
\text { results) }\end{array}$ & & $\begin{array}{l}\text { Regular } \\
\text { group } \\
7 \mathrm{st} \\
\text { (initial } \\
\text { results / } \\
\text { final } \\
\text { results) }\end{array}$ & $\begin{array}{l}\text { Control } \\
\text { group } \\
7 \quad \text { st } \\
\text { (initial } \\
\text { results } \\
\text { final } \\
\text { results) }\end{array}$ \\
\hline 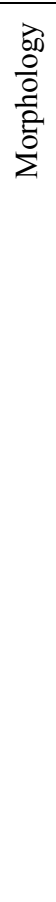 & $\begin{array}{l}\stackrel{0}{0} \\
\stackrel{0}{>}\end{array}$ & $\begin{array}{l}\text { The use of } \\
\text { tense/aspect forms } \\
\text { Present Simple / } \\
\text { Present Continuous, } \\
\text { Present Perfect / Past } \\
\text { Indefinite, Past } \\
\text { Indefinite /Past } \\
\text { Perfect, Present } \\
\text { Perfect /Present } \\
\text { Perfect Continuous } \\
\text { The use of voice } \\
\text { forms (active / } \\
\text { passive) } \\
\text { The use of Mood } \\
\text { forms } \\
\text { The use of Modal } \\
\text { verbs } \\
\text { Verb government } \\
\text { Phrasal verbs } \\
\text { Reflexive verbs } \\
\text { Sequence of tenses }\end{array}$ & $\begin{array}{l}6 \\
\text { students } \\
(50 \%) / \\
5 \\
\text { students } \\
(42 \%)\end{array}$ & $\begin{array}{l}6 \\
\text { students } \\
(50 \%) / \\
2 \\
\text { students } \\
(17 \%)\end{array}$ & $\begin{array}{l}\text { The use of } \\
\text { tense forms } \\
\text { (Präsens, } \\
\text { Präteritum, } \\
\text { Perfekt, } \\
\text { Futurum) } \\
\text { The use of } \\
\text { tense forms in } \\
\text { the active and } \\
\text { passive voice. } \\
\text { Conjugation } \\
\text { of verbs in } \\
\text { Präsens, } \\
\text { Präteritum } \\
\text { The } \\
\text { Imperative } \\
\text { Mood } \\
\text { The } \\
\text { Subjunctive } \\
\text { Mood } \\
\text { The use of } \\
\text { Modal verbs } \\
\text { Reflexive } \\
\text { Verbs } \\
\text { Verb }\end{array}$ & $\begin{array}{l}7 \\
\text { students } \\
(100 \%) \\
/ \\
\text { students } \\
(100 \%)\end{array}$ & $\begin{array}{l}7 \\
\text { students } \\
(100 \%) \\
/ \quad 5 \\
\text { students } \\
(71 \%)\end{array}$ \\
\hline
\end{tabular}




\begin{tabular}{|c|c|c|c|c|c|c|c|}
\hline & & & & & $\begin{array}{l}\text { Management } \\
\text { Sequence of } \\
\text { tenses }\end{array}$ & & \\
\hline & $\stackrel{\Xi}{\Xi}$ & $\begin{array}{l}\text { Formation of plural } \\
\text { forms } \\
\text { Use of definite / } \\
\text { indefinite / zero } \\
\text { articles }\end{array}$ & $\begin{array}{l}4(33 \%) \\
/ / 3 \\
(25 \%)\end{array}$ & $\begin{array}{l}3(25 \%) \\
/ 1(8 \%)\end{array}$ & $\begin{array}{l}\text { Declension of } \\
\text { nouns } \\
\text { Formation of } \\
\text { plural forms } \\
\text { Use of definite } \\
/ \text { indefinite / } \\
\text { zero articles }\end{array}$ & $\begin{array}{l}7 \\
(100 \%) \\
/ \\
(86 \%)\end{array}$ & $\begin{array}{l}7 \\
(100 \%) \\
/ \\
(57 \%)\end{array}$ \\
\hline & : & $\begin{array}{l}\text { Degrees of } \\
\text { comparison } \\
\text { The order of } \\
\text { adjectives in phrases }\end{array}$ & $\begin{array}{l}2(17 \%) \\
/ 1(8 \%)\end{array}$ & $\begin{array}{l}3(25 \%) \\
/ 0(0 \%)\end{array}$ & $\begin{array}{l}\text { Degrees of } \\
\text { comparison } \\
\text { Declension of } \\
\text { adjectives }\end{array}$ & $\begin{array}{l}7 \\
(100 \%) \\
/ \\
(86 \%)\end{array}$ & $\begin{array}{l}7 \\
(100 \%) \\
/ \\
(57 \%)\end{array}$ \\
\hline & 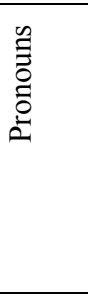 & $\begin{array}{l}\text { The absolute form of } \\
\text { possessive pronouns }\end{array}$ & $\begin{array}{l}2(17 \%) \\
/ 1(8 \%)\end{array}$ & $\begin{array}{l}11(8 \%) \\
/ 0(0 \%)\end{array}$ & $\begin{array}{l}\text { Declension of } \\
\text { personal, } \\
\text { possessive, } \\
\text { indicative, } \\
\text { indefinite } \\
\text { pronouns } \\
\text { Pronominal } \\
\text { adverbs } \\
\end{array}$ & $\begin{array}{l}7 \\
(100 \%) \\
/ \\
(71 \%)\end{array}$ & $\begin{array}{l}7 \\
(100 \%) \\
/ \\
(57 \%)\end{array}$ \\
\hline & 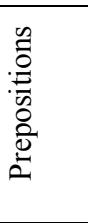 & 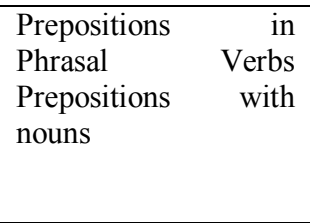 & $\begin{array}{l}2(17 \%) \\
/ \quad 2 \\
(17 \%)\end{array}$ & $\begin{array}{l}4(33 \%) \\
/ 1(8 \%)\end{array}$ & $\begin{array}{l}\text { Prepositions } \\
\text { used with } \\
\text { Dativ, } \\
\text { Akkusativ, } \\
\text { Genitiv, Dativ } \\
\text { vs Akkusativ }\end{array}$ & $\begin{array}{l}7 \\
(100 \%) \\
/ \\
(71 \%)\end{array}$ & $\begin{array}{l}7 \\
(100 \%) \\
/ \\
(43 \%)\end{array}$ \\
\hline & 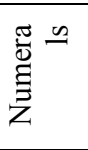 & $\begin{array}{l}\text { Cardinal } \\
\text { (Quantitative) and } \\
\text { ordinal numerals }\end{array}$ & $\begin{array}{l}3(25 \%) \\
/ \quad 2 \\
(17 \%)\end{array}$ & $\begin{array}{l}3(25 \%) \\
1(8 \%)\end{array}$ & $\begin{array}{l}\text { Cardinal } \\
\text { (Quantitative) } \\
\text { and ordinal } \\
\text { numerals }\end{array}$ & $\begin{array}{l}6(86 \%) \\
/ \quad 4 \\
(57 \%)\end{array}$ & $\begin{array}{l}5(71 \%) \\
/ \quad 2 \\
(29 \%)\end{array}$ \\
\hline 离 & $\begin{array}{l}\dot{\bar{\theta}} \\
\dot{0} \\
0 \\
0 \\
\dot{0} \\
\dot{3}\end{array}$ & $\begin{array}{l}\text { Word order in simple } \\
\text { sentences } \\
\text { Word order in } \\
\text { interrogative } \\
\text { sentences, in } \\
\text { questions to the } \\
\text { subject and its } \\
\text { definition } \\
\text { Word order in } \\
\text { subordinate clauses } \\
\text { Coordination of the } \\
\text { subject and predicate } \\
\text { in the person and } \\
\text { number }\end{array}$ & $\begin{array}{l}5(42 \%) \\
/ \quad 4 \\
(33 \%)\end{array}$ & $\begin{array}{l}4(33 \%) \\
/ \quad 2 \\
(17 \%)\end{array}$ & $\begin{array}{l}\text { Word order in } \\
\text { simple } \\
\text { sentences } \\
\text { Word order in } \\
\text { interrogative } \\
\text { and } \\
\text { imperative } \\
\text { sentences } \\
\text { Word order in } \\
\text { subordinate } \\
\text { clauses }\end{array}$ & $\begin{array}{l}6(86 \%) \\
/ \quad 4 \\
(57 \%)\end{array}$ & $\begin{array}{l}5(71 \%) \\
/ \quad 2 \\
(29 \%)\end{array}$ \\
\hline & 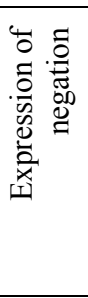 & $\begin{array}{l}\text { The absence of } \\
\text { double negation in } \\
\text { the English sentence, } \\
\text { answers to questions } \\
\text { with negation, to tag } \\
\text { questions } \\
\text { Construction neither } \\
\text {... nor }\end{array}$ & $\begin{array}{l}2(17 \%) \\
/ 1(8 \%)\end{array}$ & $\begin{array}{l}4(33 \%) \\
/ 1(8 \%)\end{array}$ & $\begin{array}{l}\text { Expression of } \\
\text { negation with } \\
\text { the help of } \\
\text { nicht, kein } \\
\text { Expression of } \\
\text { negation with } \\
\text { niemand, } \\
\text { nichts, nie }\end{array}$ & $\begin{array}{l}6(86 \%) \\
/ \quad 4 \\
(57 \%)\end{array}$ & $\begin{array}{l}4(57 \%) \\
/ \quad 1 \\
(10 \%)\end{array}$ \\
\hline & & $\begin{array}{l}\text { The use of infinitives } \\
\text { with } \backslash \text { without to as }\end{array}$ & $\begin{array}{lr}4(33 \%) \\
/\end{array}$ & $\begin{array}{l}5 \\
(42 \%) /\end{array}$ & $\begin{array}{l}\text { The use of } \\
\text { infinitives }\end{array}$ & $\begin{array}{l}7 \\
(100 \%)\end{array}$ & $\begin{array}{l}7 \\
(100 \%)\end{array}$ \\
\hline
\end{tabular}




\begin{tabular}{|c|c|c|c|c|c|c|}
\hline & $\begin{array}{l}\text { part of the Complex } \\
\text { object }\end{array}$ & $(25 \%)$ & $2(17 \%)$ & $\begin{array}{l}\text { with \ without } \\
\text { particle } \\
\text { Infinitive } \\
\text { constructions } \\
\text { um ...zu, statt } \\
\ldots \quad \mathrm{zu} \text {, ohne } \\
\ldots \mathrm{zu}\end{array}$ & ${ }^{/}(71 \%)^{5}$ & ${ }^{/}(43 \%)^{3}$ \\
\hline 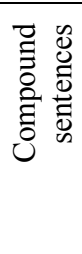 & $\begin{array}{l}\text { The use of } \\
\text { conjunctions in a } \\
\text { compound sentence }\end{array}$ & $\begin{array}{l}3(25 \%) \\
/ / 3 \\
(25 \%)\end{array}$ & $\begin{array}{l}2(17 \%) \\
/ 0(0 \%)\end{array}$ & $\begin{array}{l}\text { The use of } \\
\text { conjunctions } \\
\text { in a compound } \\
\text { sentence } \\
\text { Word order in } \\
\text { a compound } \\
\text { sentence }\end{array}$ & $\begin{array}{l}7 \\
(100 \%) \\
/ \\
(86 \%)\end{array}$ & $\begin{array}{l}7 \\
(100 \%) \\
/ \quad 4 \\
(57 \%)\end{array}$ \\
\hline 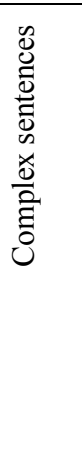 & $\begin{array}{l}\text { Different types of } \\
\text { subordinate clauses } \\
\text { (relative clauses, } \\
\text { attributive clauses, } \\
\text { clauses of reason, } \\
\text { purpose, concession, } \\
\text { time, etc.) }\end{array}$ & $\begin{array}{l}3(25 \%) \\
/ \quad 2 \\
(17 \%)\end{array}$ & $\begin{array}{l}5(42 \%) \\
/ 1(8 \%)\end{array}$ & $\begin{array}{l}\text { Different } \\
\text { types of } \\
\text { subordinate } \\
\text { clauses } \\
\text { (relative } \\
\text { clauses, } \\
\text { attributive } \\
\text { clauses, } \\
\text { clauses of } \\
\text { reason, } \\
\text { purpose, } \\
\text { concession, } \\
\text { time, etc.) }\end{array}$ & $\begin{array}{l}7 \\
(100 \%) \\
/ \\
(86 \%)\end{array}$ & $\begin{array}{l}6(86 \%) \\
/ / 3 \\
(43 \%)\end{array}$ \\
\hline 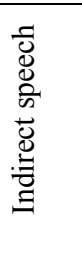 & $\begin{array}{l}\text { Sequence of tenses } \\
\text { when transferring } \\
\text { from direct speech } \\
\text { into } 4 \text { indirect, } \\
\text { changing personal } \\
\text { and demonstrative } \\
\text { pronouns }\end{array}$ & $\begin{array}{l}5(42 \%) \\
/{ }_{(33 \%)} 4 \\
(33 \%)\end{array}$ & $\begin{array}{l}5(42 \%) \\
/ 2 \\
(17 \%)\end{array}$ & & & \\
\hline
\end{tabular}

The degree of formation of grammar skills in oral and written speech is indicated by the mistakes made by students. In relation to the English language native Russian students, as a rule, have problems, mastering the use of tense forms, especially Present Simple / Present Continuous, Present Perfect / Past Indefinite, Past Indefinite /Past Perfect, Present Perfect /Present Perfect Continuous, the link verb to be. Even the use of notional verbs in the third person singular without $-\mathrm{s} \mid$-es is not that rare. These mistakes almost reach $1 / 2$ of all registered grammar errors. The primitive nature of the errors is evident in cases of misuse of articles, prepositions, pronouns. Verbal forms, non-finite constructions, moods, prepositions, word order (especially in interrogative sentences) cause lots of mistakes due to the existence of substantial differences of structures in the Russian language. With regard to the German language, in addition to some problems with the assimilation of specific temporal verb forms, there are certain difficulties with the use of the declension of nouns, adjectives, pronouns, as well as frequent syntax errors due to the ignorance of word order rules.

In Russia German is very often taught as L3, therefore, German acquisition by Russian native speakers can sometimes be influenced by English as L2. Belonging to the Germanic branch of Indo-European language family English and German have grammar systems that can be referred to as analytical, while the Russian language (which was the native language of the participants of the experiment) is a synthetic language. This factor considerably complicates the process of acquisition of analytical features of the target languages [7]. 
On the level of morphology a greater number of active verbal tense forms in the target languages (16 in English and 6 in German) in contrast to the limited number existing in native Russian explained the amount of mistakes made by the learners in this field at the initial stage of the experiment. In spite of the fact that the Russian native learners are familiar with the category of declension, this grammar aspect still presents a problem while learning German, due to the fact that the declension system of this language is more morphologically developed than in English. In English it is only the Genitive Case that is typical of nouns whereas in German there are four cases which are expressed by inflections in nouns, adjectives, participles and pronouns. Besides, English lacks the category of gender which makes German grammar even more difficult for those who learns English as L2 and German as L3 [8,9].

On the level of syntax both English and German have a fixed word order, but Russian is characterized by a free word order. This accounts for the inability of the Russian learners to construct correct affirmative, interrogative or negative sentences at the initial stage of the experiment $[10,11]$.

The results of the comparative analysis of the languages predetermined our choice of exercises offered to the control group students during the experimental period.

\section{Results}

The mistakes made by learners are predetermined by different grammatical features of the target languages and their native language. They were detected through the diagnostic tests and may be classified into two groups: 1) mistakes made due to a wrong grammar unit formation and 2) mistakes made due to the inability to understand the function of a grammar unit. Depending on the nature of errors there were developed certain training plans. The results showed that the receptive language abilities of the Russian native learners prevail over their productive language skills.

The mistakes of the first kind were eliminated through regular repetition of the right forms. The following exercises were included into the classroom activities: imitation exercises, substitution drills, transformation exercises. Even at this stage of L2 acquisition we asked the control group not only automatically construct sentences analogical to the given examples, but make their choice of forms by contrasting them to each other in the table of possible answers by means of comparing the target and native language means. The selected training materials helped to develop automatic grammar skills so that at the end of the experimental period the students could easily and effortlessly select the correct grammar forms when performing oral or written activities.

The mistakes of the second type, which indicate how well the grammatical ability is formed in a particular student, were harder to work with since such errors demand reflection and analysis of the immediate context.

First of all, at this stage of L2 grammar acquisition the emphasis was laid on the developing of productive rather than reproductive skills. Besides, a reflective and translanguaging approaches were applied in the classroom. The transformation of grammatical skills into grammatical abilities in English or German was facilitated by a range of exercises which offer to use a grammar form spontaneously according to the speech situation without a given list of options. The students were taught to reflect upon the structure of a sentence, the role of verbs, nouns, adjectives, adverbs and their forms as well as the meaning of different grammar units in a text. Instead of isolated sentences we presented coherent texts for analysis to our learners. It should be noted that the tasks for comparison and categorizing the use of different grammar units in the target language and the native language proved to be very effective for reinforcing grammar skills in English and German. 
Secondly, we found it very important to encourage our students to use their target language as a tool for general cognition. The projects motivating students' curiosity and desire to learn new things were included into the teaching plan. The tasks and topics for the projects were selected and formulated in accordance with the students' preferences and spheres of interest. Mind mapping was recommended to the learners as a productive technique for collecting and structuring the information for their projects. The experimental group students were made aware of the importance to learn how to build new structures using analytical skills and meta-disciplinary knowledge rather than reproduce ready-made constructions.

Thirdly, the translanguaging approach is closely related to the concept of national identity and national linguaculture. In the context of cross-cultural communication L2 or L3 acquisition can only be successful if guided by the native linguaculture system in teaching English and German. Since one's own linguacultural identity manifests itself better through the contact with another culture, we compared language phenomena and cultural components in the native and target languages. This analysis helped to prognose difficulties which learners might face when acquiring another language and select the right teaching methods to overcome these difficulties. The exercises and teaching materials used in our practice reflected the idea of synchronous study of a language and a culture. Comparing cultural, linguistic, social phenomena, acceptance of the right of other cultural values to exist and awareness of cultural diversity are the necessary preconditions of acquisition of both native and foreign languages [12].

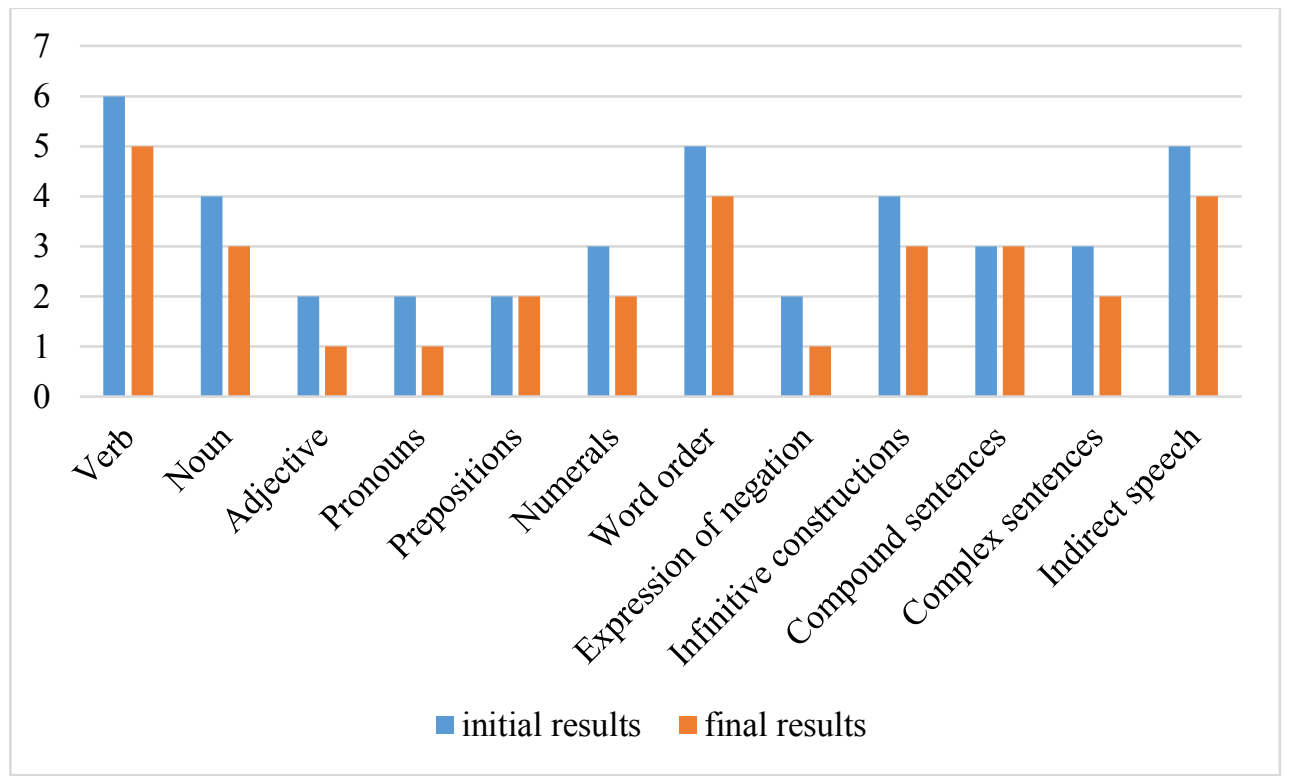

Fig. 1. Progress in grammar acquisition in the regular English group. 


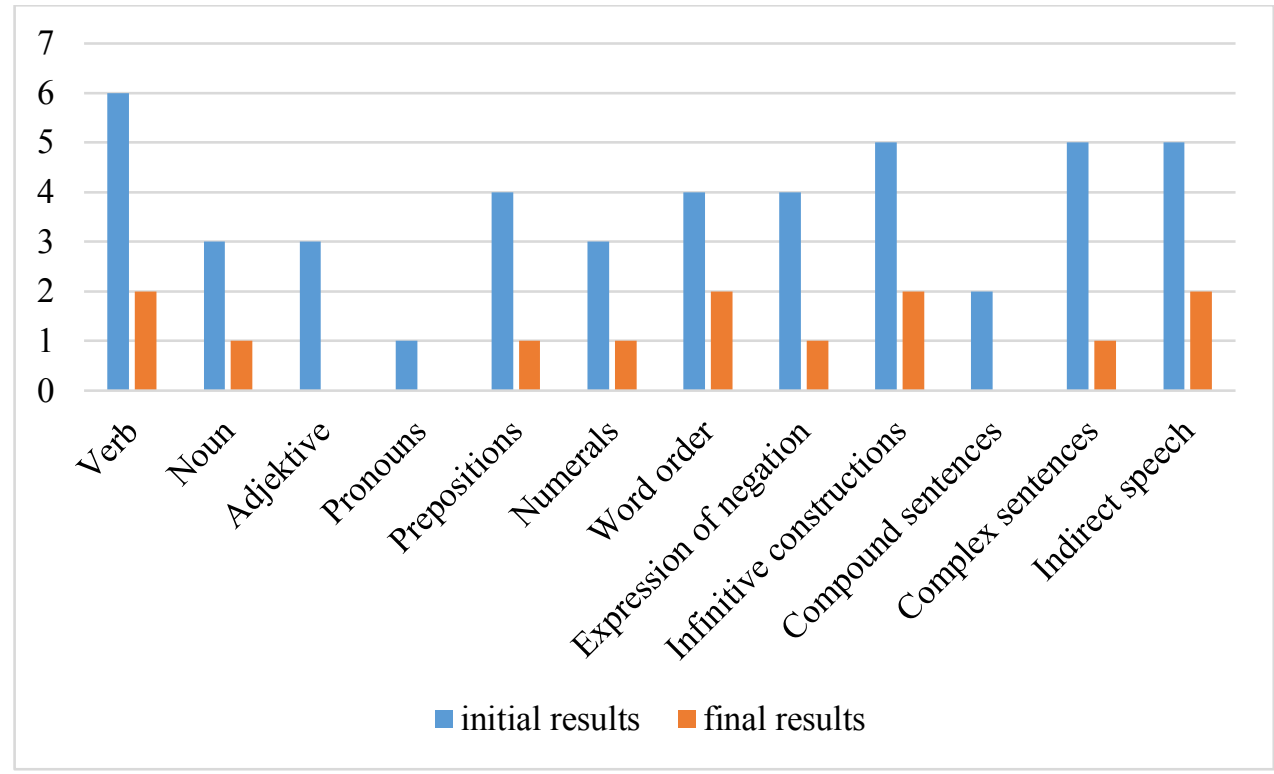

Fig. 2. Progress in grammar acquisition in the control English group.

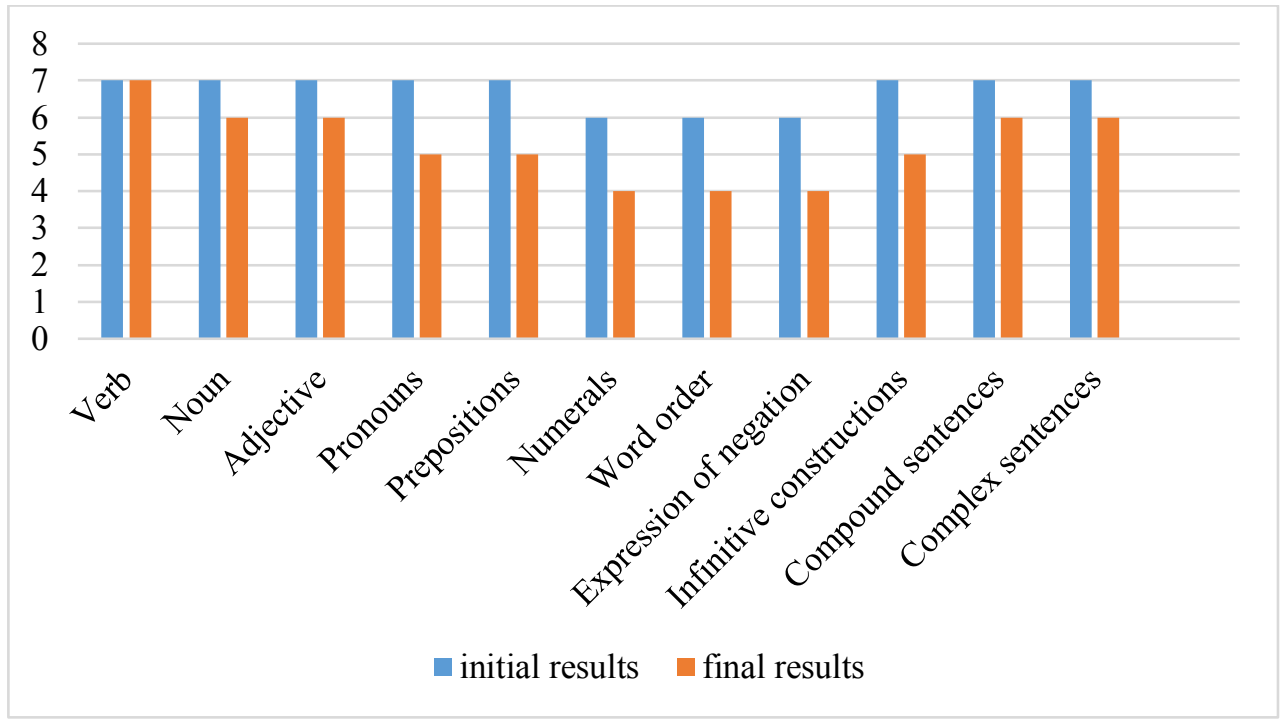

Fig. 3. Progress in grammar acquisition in the regular German group. 


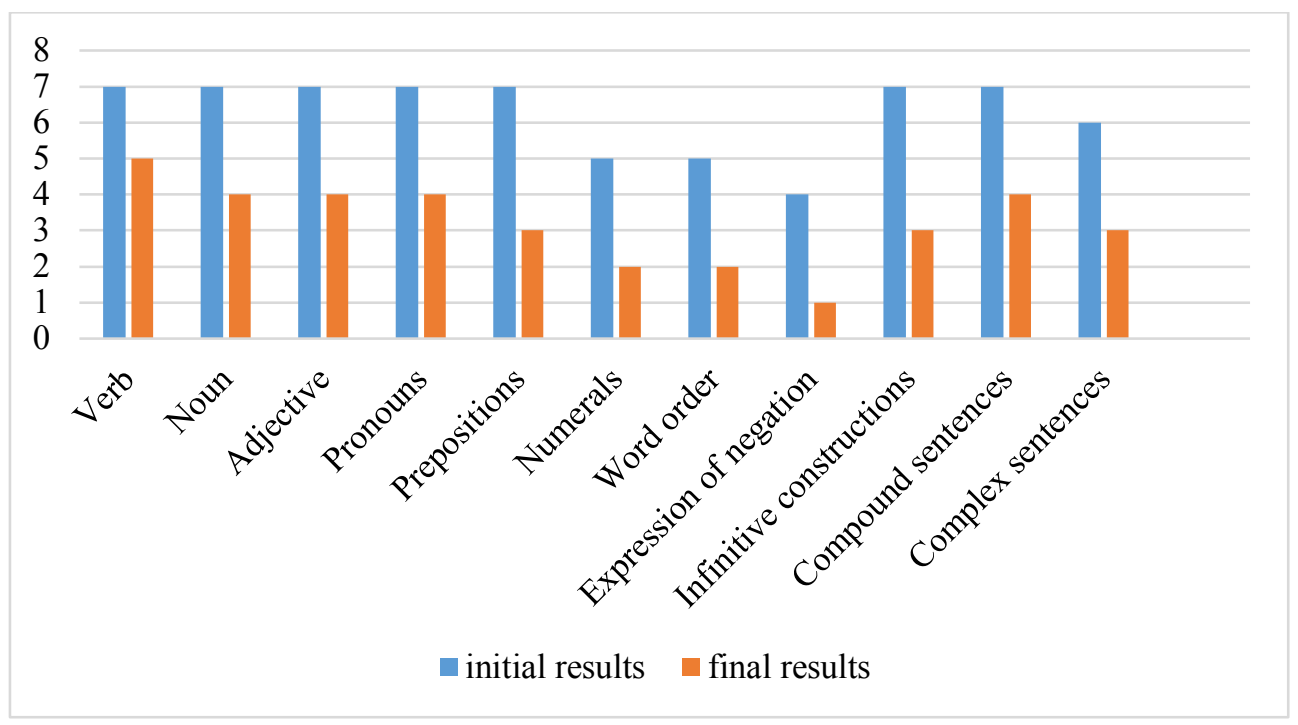

Fig. 4. Progress in grammar acquisition in the control German group.

\section{Discussion}

There have been a lot of debates whether only the target language should be used in a classroom or the means of the native language could be successfully employed in the teaching process. Even though immersion environment recreated at the lesson by only speaking English or German while teaching may be quite an effective way to boost students' communicative skills, a thorough understanding of grammatical categories and ways of how a language system really works can only be achieved by drawing parallels between the already acquired language concepts and those which are currently under the study. It is the continuity of language acquisition that produces fruitful results and consistent studying activities based on the skills and knowledge gained naturally while learning the mother tongue lead to proficiency in L2 and L3 and to bilingualism or multilingualism [13].

The present study proves that the application of translanguaging approach to teaching English and German grammar to Russian native speakers helped the learners to establish strong interconnections between the Russian grammar phenomena and those of the target languages. The teaching activities selected carefully according to the initially detected problematic fields in the studied grammars focused on the comparison of grammar features of the languages. Thus, the reduction in the number of mistakes at the end of the experiment leads to the conclusion that our method is an effective mechanism of elimination of grammar errors. This practice should be adopted in Russian comprehensive schools to improve students' proficiency in grammar of L2 or L3 and to make students translingual. Introducing the approach of learning a language as an activity rather than an isolated system implies collecting information by means of both languages: native and studied. It was taken into account when working on the exercises for the control group and it turned out to be very successful. When a learner processes the information gained through general cognition by means of two or more languages and uses metalinguistic practices working with a new grammar element it enables the learner to achieve a high level of language proficiency and to develop language intuition $[14,15]$. 


\section{Conclusions}

To conclude, the study showed that teaching English or German grammar to Russian native speakers brings positive results and significantly decreases the number of grammar mistakes only when teachers rely on the skills and knowledge gained by students when learning their mother-tongue. This field of linguistics and teaching theory can be further researched from the perspective of lexical acquisition or development of communication skills. Learning and teaching a language must be viewed as a way of introduction to a culture not only as means of communication. It allows to create learning situations which are very close to reality. High language proficiency is achieved by equal exposure of students to both languages and cultures when one's own national identity becomes clearer and more tangible through the contact with a foreign culture. Concurrent study of language and culture results in the acceptance of the right of other cultures to exist which has utmost importance in the modern multilingual and polycultural world. Personal cultural experience is always prior when contacting a foreign culture. Acquiring new cultural phenomena students always expand the capacity of their perception of the world. Bringing discussion of current problems such as racism, discrimination, extremism, ethnocentrism, etc. into the classroom makes students aware of the necessity of a qualitative approach to language study as a step to cultural integration into world community.

\section{References}

1. O. García, Wei Li, Translanguaging: Language, Bilingualism and Education (London, Palgrave Macmillan, 2014)

2. O. García, Bilingual education in the 21st century: A global perspective (Oxford and Chichester, Wiley-Blackwell, 2009)

3. J. Cenoz, D. Gorter, Multilingual Education: Between language learning and translanguaging (Cambridge, Cambridge University Press, 2015)

4. A.

Bier,

EL.LE

4(1)

https://www.researchgate.net/publication/308783992_An_Exploration_of_the_Link_be tween_Language_and_Cognition_From_Vygotsky's_Sociocultural_Theory_to_CLIL

5. J.W. Lee, Critical Inquiry in Language Studies 11(1), 50 (2014)

6. Ahrenholz Bernt, Oomen-Welke, Ingelore: Deutsch als Zweitsprache. Deutschdidaktik in Theorie und Praxis Band 9. 2. überarb (Aufl. Baltmannsweiler, 2010)

7. Beste Gisela, Deutsch Methodik. Handbuch für die S I und II (Berlin, 2007)

8. Ortwin Beisbart, Marenbach, Dieter: Bausteine der Deutschdidaktik. Ein Studienbuch 3 (Aufl. Donauwörth, 2009)

9. Günter Lange, Weinhold, Swantje: Grundlagen der Deutschdidaktik. SprachdidaktikMediendidaktik - Literaturdidaktik 3 (Aufl. Baltmannsweiler, 2007)

10. O.P. Shkurina, Comparative analysis of German and English as Germanic branch of Indo-European language system. $V$ mire nauki $i$ iskusstva: voprosy filologii, iskusstvovedeniya i kul'turologii: sb. st. po mater. XXI mezhdunar. nauch.-prakt. konf. (Novosibirsk, SibAK, 2013)

11. J. MacSwan, Grammatical theory and bilingual codeswitching (Cambridge, MA, MIT Press, 2014)

12. J. MacSwan, American Educational Research Journal 54(1), 167 (2017)

13. J. Cummins, Encyclopedia of Language and Education 5(2), 65 (2008)

14. M. Swain, P. Kinnear, L. Steinman, Sociocultural Theory in Second Language 
Acquisition: An Introduction through Narratives (Bristol, Multilingual Matters, 2011)

15. L. Wei, Translanguaging as a Practical Theory of Language, Applied Linguistics (Oxford University Press, 2017) https://www.researchgate.net/publication/320960187_Translanguaging_as_a_Practical _Theory_of_Language 